\title{
Exploration on the Reform and Innovation of the Training Modes for Applied Technical Talents in Transitional Colleges and Universities
}

\author{
Manli Zou \\ Nanyang Institute of Technology, Nanyang 473004, China \\ nylgzml@126.com
}

Keywords: Transition; Colleges and universities; Applied technical; Talent training mode reform; Innovation

\begin{abstract}
For transitional colleges and universities, there are no existing fixed format for the reform and innovation of the training modes for applied technical talents, thus bold practices and explorations are needed. At present, transitional colleges and universities need to fully realize the current condition and importance of the reform and innovation of the training modes for applied technical talents. Based on this, they can learn positively from the excellent talent training modes in both domestic and foreign counterparts, combine their own educational actuality, explore actively the applied talent training modes that conform to the national condition of China and then cultivate high-quality engineering technical talents that have strong innovative abilities and conform to the needs for economic and social development so as to lay solid human resource advantages for the construction of innovative countries and realization of both industrialization and modernization.
\end{abstract}

\section{Introduction}

Currently, China is in a crucial moment of accelerating the transformation of economic development modes, promoting the adjustment and upgrading of industrial structures and comprehensively deepening the reform, which requires the higher education to provide the modern production and service frontline with applied, inter-disciplinary and innovative talents that not only possess modern scientific and technological knowledges but also receive systematic skill trainings, especially the high-end technical and skilled talents in the industry chain. Hotheyver, the current phenomenon of "labor shortages of enterprises" and "unemployment of new graduates" also demonstrates that currently there exist large gaps bettheyen the graduates cultivated by China's colleges and universities and the demands of the society for talents. Thus, for transitional applied technical colleges and universities, the reform and innovation on the training mode for applied technical talents and the improvement of talent training qualities is an important subject that should be solved urgently and has decisive significances for the improvement of colleges and universities themselves.

\section{The reform and innovation on the talent training mode is the core and key for the deep transition of newly-established local applied colleges and universities}

The goal for the transitional development of Newly-established local undergraduate universities is to build the high-level applied undergraduate universities through content development and the fundamental orientation is to cultivate high-level applied talents that conform to the industrial transition \& upgrading and the development of social services and improve the level and ability of serving the local and regional economy and society. Apparently, the fundamental goal of the transitional development or the key problems that can be solved through the transition is the improvement of school education qualities so as to serve the economic and social development better and more directionally. Meanwhile, the teaching quality first depends on the quality of the talent training mode. On one hand, the talent training mode is a carrier to implement the educational philosophy and educational orientation of the school; on the other hand, it also provides guarantees for the implementation of the general planning of education and teaching activities, construction of 
faculty teams, platform building for the practice and education inside and outside the campus, the cooperation bettheyen schools and enterprises, the integration of industries and educations, etc. Therefore, the reform and innovation on the talent training mode is not only the priority of higher education, but also the core and fundamental to improve the education qualities of transitional colleges and universities.

\section{Main issues in the building process of the talent training modes of transitional colleges and universities}

3.1 The insufficient understanding of transitional colleges and universities for the importance of talent training modes in the cultivation of applied talents

For colleges and universities, the quality of the talent training first depends on the quality of the talent training mode, because the talent training mode is not only the carrier to realize the educational philosophy, orientation and goal, but also the general planning for the talent training. Some transitional colleges and universities fail to understand comprehensively and pay enough attention to the important position of the reform and innovation on talent training modes in the cultivation of applied talents, resulting in the decline of the general transitional effects, the difficulty to deepen and ensure the quality of applied talent trainings and the failure to realize the expected training results. At present, some transitional colleges and universities have explored and implemented some effective talent training modes, such as the training mode which is based on the " $3+1$ " school-enterprise cooperation mode for excellent applied talents including excellent engineers, excellent physicians, excellent legal talents and excellent teachers, the applied talent training mode based on the curriculum setting pattern of "platform + module", the applied talent training mode based on the "school-school" cooperation bettheyen Chinese colleges \& universities and foreign counterparts as theyll as the CDIO and OBE modes put forward by foreign countries. Hotheyver, there is still a lack of training forms for applied talents which cannot satisfy the needs for the cultivation of a variety of applied talents. Thus, they still need to make reforms and innovations on the talent training mode, boost the vitality of talent training modes and give full play to the core and key role of applied talent training modes in the training process and quality improvement process for applied talents in transitional colleges and universities

3.2 The insufficient researches of transitional colleges and universities on applied talent training modes and backward theoretical researches

Currently, with the constant expansion of applied technical university alliances (reaching over 150) and an increasing number of various alliances, the cooperation and exchanges among alliance colleges and universities, bettheyen domestic and international colleges \& universities as theyll as bettheyen enterprises and schools have been intensified. Meanwhile, the transitional colleges and universities have made remarkable practicing results in the reform and innovation on the applied talent training modes. Hotheyver, relevant theoretical researches on this area are still lagging behind. Apparently, people have paid wider and wider attention to the transitional development of theoretical researches. With an expanding research team and constantly deepening achievements, the theoretical researches have become the most important and active research area, though there are still a lack of deep and systematic researches on relevant key issues, such as how to make reforms \& innovations on and Transitions \& upgrading for the applied talent training modes of transitional colleges and universities to conform better to their applied talent trainings. As a result, there is still a lack of guidance in aspects including the systematic theories and reforms \& innovations while some colleges and universities or some of their applied talent training modes remain conventional, rigid and have low qualities.

\subsection{The insufficient involvement of enterprises in the building process of talent training} modes

In the actual building process of the talent training modes, most of the professional talent training modes are designed completely by colleges and universities when they are learning from the talent training modes of their counterparts. Although some colleges and universities also invite some personnel in the field to involve in the preparation and demonstration process of the talent 
training modes, the limited number, representativeness and discussion time, its understanding of the development condition of the whole industry as theyll as the effects have determined, to some extent, the insufficient depth for the involvement of industries, sectors and enterprises in building the talent training modes. In addition, there are also a lack of integrated considerations in the entrance, exit and cultivating process. Under such condition, the built talent training modes will be unsystematic, unscientific and not integrated while the talent training mode will also fail to conform to the needs of both enterprises and students and tend to have deficiencies and theyaknesses, thus influencing the quality of the talent training modes in transitional universities.

\subsection{The insufficient importance attached to the practice education}

With the reform and advancement of the applied talent training modes in transitional colleges and universities, there has been an increasing proportion of practice education in the curriculum system, but there are still many structural deficiencies, including the insufficient attention to the cultivation of innovative and entrepreneurial abilities, theyak procedures of practice teaching, large gaps bettheyen the practice education and the applied talent training requirements, immature system for the practice teaching, insufficient modeling and systematic approaches of the practice teaching, divorce from the actual needs of industries and enterprises, severe fragmentation of courses, insufficient support of courses and modules for the cultivation of knowledges, qualities and abilities required by the training goal, insufficient attention paid to the curriculum construction, lack of characteristic materials facing both the projects and products, backward methods of the practice teaching, separation bettheyen the practice contents and the development of social economy as theyll as the fact that the construction of the practice teaching base are lagging behind the requirements of the teaching development. As a result, the graduates will have incomplete structures of knowledges and skills, theyak manipulative abilities, deficient innovative spirits and severe shortage of abilities of environmental adaptation and professional transfer.

\subsection{Lack of effective supports provided by the existing faculty team for applied talent trainings}

Looking at the faculty condition of newly-established graduate colleges and universities currently in China, most young teachers go to work in the newly-established graduate colleges and universities immediately after the graduation, resulting in their lack of manipulative abilities, practice teaching procedures, engineering application background and the understanding and concepts of transitions. Part-time teachers from enterprises can integrate knew knowledges, new technologies and new questions into the teaching of the school, which contributes to the cultivation of students' innovative abilities and practical abilities. These teachers typically have instantly available practice experiences, but are lacking in corresponding professional trainings and combinations with theoretical knowledges and they often feel helpless and disturbed in the process of class teaching. Meanwhile, there are a lack of strong faculty teams that support the student trainings (or the mixed faculty team), which cannot satisfy the needs of the talent training modes. Therefore, the priority is to enable these school teachers to make up for the course of enterprise practices in a short time as soon as possible and improve the engineering application ability of the faculty team.

\section{Exploration on the path of reform for the applied technical talent training modes of transitional colleges and universities}

4.1 Updating the concepts and attaching great importance to the core position of the talent training mode in the applied talent training

Changing the education philosophy and updating the education concepts are the ideological basis and leading guidance for the applied talent training. To ensure the solid reform and innovations on the talent training modes, the updating of educational philosophies is both the prerequisite and key. The applied talent training modes of transitional colleges and universities focus on the word, "application”, which requires us to take the educational thoughts and concepts that can embody the sprits of the times and the demands for social development as the leading guidance, update the educational thoughts, changing the educational concepts, liberalizing the mentality, seek 
truth from facts, keep pace with the times and establish systems with innovations. Meanwhile, they should also take the engineering demands of the enterprise as the orientation, adhere to the educational concept of "originating from engineering practices, innovating engineering practices and guiding engineering practices”, establish the new discipline orientation, professional structure, curriculum structure, teaching content, teaching methods and teaching means that can satisfy and conform to the needs of economic and social development, improve the teaching level comprehensively and build the training mode for high-level technical and skilled talents with strong social adaptabilities and competitiveness.

\subsection{Strengthening the research and facilitating the reform and innovation on the applied talent training of transitional colleges and universities}

From the macro perspective, the applied talent is not only the results of the social modernization development in China, but also the inevitable choice for the diversified development of higher education; From the micro perspective, it can not only satisfy the demands of social employers for talents, but also meet the demand of many families and students for both the higher education and the employment. Sustained and deep researches are needed to strengthen the applied talent training modes of transitional colleges and universities. The most essential characteristic of the applied talents from transitional colleges and universities is to have more abundant theoretical knowledges than students from higher vocational colleges do and stronger practical abilities than undergraduates do. Therefore, they should introduce the demands of enterprises and industries for talents into the formulation of the talent training mode through cooperation bettheyen schools and enterprises and take the demands, employment and qualities as the orientation of the applied talent training mode. Besides, they should also stick to the principle of "adaptations to local conditions and dynamic development", make reforms on the talent training mode, formulate different talent training modes according to different demands and orientations and establish systematically a talent training mode with the integration of entrance, exit and training. Through comprehensive and multi-level researches, they can improve the talent training plans and training paths, conform better to the talent training goal and training specifications and meet the demands of the society better.

4.3 Strengthening the construction of the platform for school-enterprise cooperation and promoting the deep integration bettheyen the industries and education

Strengthening and deepening the cooperation bettheyen the local applied graduate colleges \& universities and the enterprises and promoting the integration bettheyen industries and education is an important path for transitional colleges and universities to train the applied talents. In the cooperation bettheyen the school and enterprise, they need to emphasize the role of the enterprise, form an educational system and mechanism led by the government, guided by the industry and involved by the enterprise and give full play to their advantages in aspects including the industrial planning, funding measures, advanced technological applications, part-time teacher recruitment (appointment), enterprise internship and promote the employment of students. Furthermore, they should promote the deep cooperation between the school and enterprise, strengthen the educational vitality of the school, deepen the reform on the internal human resource management system of the school, carry forward the responsibilities of the close contact bettheyen teachers and enterprises, guide and inspire teachers to serve the enterprise and society actively, start the R \& D of technologies, promote the transformation of scientific and technological fruits and realize the mutual benefits and win-win results. In addition, the cooperation bettheyen the school and enterprise can also be made in many aspects including jointly developing courses and compiling textbooks, jointly establishing teaching teams, jointly guiding the graduation design and jointly constructing the practice base, so as to enable the students to acquire relatively comprehensive skill trainings and post experiences.

\subsection{Facing the engineering actuality and restructuring the practice education system}

Practice education is not only an important procedure to realize the applied talent training mode, but also a key approach to cultivate the systematic thinking, manipulative abilities and innovative abilities of college students. Transitional colleges and universities need to strengthen the practical and applied teaching. First of all, they should focus on the construction of students' innovative 
knowledge structures, break the closure of courses, pay attention to the development of innovative courses, strengthen the practical teaching procedures and cultivate the innovative abilities of students. Secondly, they should reduce the proportion of verification experiments and increase the proportion of designing, comprehensive, innovative and open experiments in order to cultivate the professional designing ability and practical innovative ability of students. Thirdly, they should not only improve the system for students' experiments and practice in the school, internship and practice in the enterprise and holiday internship, but also conform strictly to the requirements of the ministry of education in which the intern and practice course should take up no less than $30 \%$ so that the students can acquire at least one year's practice and internship. Fourth, they should strengthen the construction of experimental, internship and practice base, take the ability as the orientation, combine closely the theories with experiments and practices and form a pattern where classes overlap with the laboratory, practice base and production workshop.

\subsection{Strengthening the construction of double-qualified faculty team and building the mixed faculty team}

Colleges \& universities and enterprises should establish a school-enterprise mixed faculty team related to the talent training mode through the integration between the industry and education and synergistic innovation so as to cultivate talents jointly. On one hand, they should invite enterprise backbones with strong practicing experience to take up certain teaching tasks in the school and participate in the formulation and revise of professional talent training plans. On the other hand, they should rely on the enterprises to strengthen the training, persuade teachers to work in the enterprise in an organized and purposeful way and improve their abilities of engineering application. Thirdly, teachers from colleges and universities and relevant personnel in the enterprise and industry should develop the topic jointly and realize common progresses. Furthermore, they should also implement the mutual part-time system for teachers and engineers from the enterprise, ensure their reasonable and effective flow between the school and enterprise, strengthen the construction of engineering faculty teams and form a high-level faculty team to ensure the successful implementation of the applied talent training and achieve expected results.

\section{Conclusion}

Guiding the transitional development of some newly-established graduate colleges and universities is not only one of the national strategies for the structural adjustment and development promotion of higher education, but also the historical responsibility and important opportunity for colleges and universities to serve actively the transition of economic society and strengthen the construction of contents. Meanwhile, the sustained reform and innovation on the talent training modes is not only the core for the deep transition of colleges and universities and an important issue that must be solved properly, but also the key to the transition and improvement of the quality of applied talent trainings. The reform and innovation on applied technical talent training modes of transitional colleges and universities is a systematic project that involves various aspects of talent trainings and must be planned with full considerations and implemented orderly. Therefore, local newly-established colleges and universities should actively change the inertial mindset, transform traditional educational philosophies, positively respond to and carry forward national strategies concerning the "guidance for the transition of local graduate colleges and universities" and "construction of modern professional education system", actively explore the transitional path and methods that conform to social development and meet the needs of the development of colleges themselves. Furthermore, they should make reforms and innovations on the training mode for applied technical talents and then cultivate high-quality engineering technical talents that have strong innovative abilities and conform to the needs of economic and social development so as to lay solid human resource advantages for the construction of innovative countries and realization of both the industrialization and modernization. 


\section{References}

[1] Zhangwang, Du Yali, Dingwei. Reality Reflection and Contemporary Innovation for Personnel Training Mode [J].Educational Research, 2015（01）.

[2] Zhong Binglin. Reform on Personnel Training Modeas Core Connotation Construction for Institution of Higher Learning[J].Higher Education Research， 2013 (11).

[3] Li Liguo.Personnel Training Mode of Higher Education in Industrial 4.0 era [J].Tsinghua Journal of Education, 2016 (01).

[4] Wang Lixia, Daixi, Liuhuanjun. Theoretical Study on “2+2”Applied Personnel Training Mode[J].Research in Higher Education of Engineering,2015(01).

[5] Liu Yinghua. Research on Applied Undergraduate Personnel Training Mode in Local Colleges and Universities [D].Jiangxi:Jiangxi Science and Technology Normal University, 2015.

[6] Zhou Xuhong. Current Situation and Outlook of Reform and Innovation of Chinese Engineering Education Personnel Training Mode-Special Report in International Engineering Education Forum 2015[J].Research in Higher Education of Engineering,2016 (01) .

[7] Sun Huiming.Present Situation Research on Innovative Personnel Training Mode Reform in China's Colleges and Universities[D].Jiangxi:Jiangxi Science and Technology Normal University, 2015. 